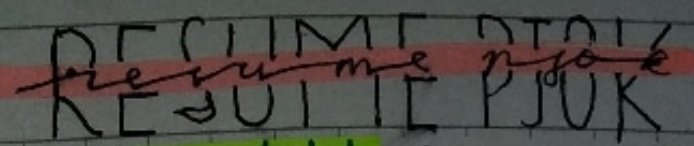

Permainan bola voli a dalah permarnan beregu yang masing? regu terdir dari 6 orang dengan rujuan menjaruhkan bola ke arah lawan dan mencapal game terlebih dahulu

\title{
Teknik dasar:
}

service, passing, smash, block

Teknik bola voli servis

servis bawah jenis servis yang paling mudah diakukan kelemahan service bawah adalah bola mudah diterima musuh.

servis atas : Banyak vartasi tekniknya:

a. Mengambang (floating)

b. Top spin

c. Mengambang melingkar

Teknik bola voli passing

1.passing bawah 2.passing atas

Teknik bola volismash.

pukulan yang tajam keras, dan menutik ke arah lawan.

Gerakan smash : awalan : nelangkah 4 meter dar net. tolakan.langkah telukhir lompar dgn redua sikap akchir pukul bola seteras? ny doil menuik

Ternik bola (membendung) Tujuan : membendung smash lawan voh block (mtembendung) dapardilakukan oleh $1,2,3$ pemain 